\title{
Reflection seismic studies over the end-glacial Burträsk fault, Skellefteå, Sweden
}

\author{
C. Juhlin and B. Lund \\ Department of Earth Sciences, Uppsala Universtiy, Uppsala, Sweden \\ Received: 3 September 2010 - Published in Solid Earth Discuss.: 11 October 2010 \\ Revised: 10 December 2010 - Accepted: 29 December 2010 - Published: 7 January 2011
}

\begin{abstract}
Reflection seismic data were acquired along a ca. $22 \mathrm{~km}$ long profile over the end-glacial Burträsk fault with a nominal receiver and source spacing of $20 \mathrm{~m}$. A steeply dipping reflection can be correlated to the Burträsk fault, indicating that the fault dips at about $55^{\circ}$ to the southeast near the surface. The reflection from the fault is rather poorly imaged, probably due to a lateral offset in the fault of about $1 \mathrm{~km}$ at this location and the crookedness of the seismic profile in the vicinity of the fault. A more pronounced steeply dipping reflection is observed about $4 \mathrm{~km}$ southeast of the Burträsk fault. Based on its correlation with a topographic low at the surface this reflection is interpreted to originate from a fracture zone. There are no signs of large displacements along this zone as the glacial ice receded, but earthquakes could be associated with it today. Other reflections on the processed seismic section may originate from changes in lithological variations in the supra-crustal rocks or from intrusions of more mafic rock. Constraints on the fault geometry provided by the reflection seismic data will help determine what stresses were required to activate the fault when the major rupture along it occurred ca. 9500 years ago.
\end{abstract}

\section{Introduction}

Based on studies of Quaternary deposits (Lagerbäck, 1990), major continuous fault scarps in northern Sweden have been inferred to be end-glacial in age, that is fault movement occurred at or near the time that the last glacial ice receded ca. 9500 years ago. The term post-glacial is widely used in the literature (e.g. Talbot, 1986; Roberts et al., 1997), but we prefer the term end-glacial since it better describes the timing of the faulting. There has been significant disagreement on

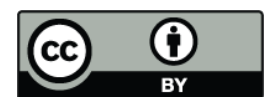

Correspondence to: C. Juhlin (christopher.juhlin@geo.uu.se) the geometry of these faults at the surface with suggestions ranging from gently dipping (Talbot, 1986; Henkel, 1988) to steeply dipping or near-vertical (e.g. Lagerbäck, 1990). Most of the faults have been interpreted to be reverse faults (Lagerbäck and Sundh, 2008). There is also general agreement that these scarps were generated by major earthquakes at the time of the glacial retreat, some with magnitudes as high as 8 (Arvidsson, 1996).

A good correlation has been found between present day seismic activity and the locations of the end-glacial faults or fault systems (Juhlin et al., 2010 and Fig. 1). However, present day earthquake magnitudes are generally less than 3. Two longstanding questions concerning the end-glacial faults of northern Sweden are (i) what was the stress field that caused these ruptures and (ii) what is the geometry of the faults at depth. These questions need to be answered in order to understand the mechanics behind the rupturing process (Lund and Näslund, 2009).

As a first step in answering the latter of these two questions, a reflection seismic survey was acquired over the Pärvie fault system (see Fig. 1 for location) in 2007 (Juhlin et al., 2010). The Pärvie fault system was chosen since the main fault of the system is the longest, at $150 \mathrm{~km}$, of all the end-glacial faults found to date. Results from this survey show dipping reflections from the end-glacial faults, as well as sub-horizontal reflections. The more sub-horizontal reflections from the area were interpreted as possibly originating from deeper lying greenstones or gabbroic bodies. Surface geological observations of the fault geometries are consistent with the location and orientation of the dipping reflections from the faults. The end-glacial faults appear to dip at moderate to steep dips down to at least $2-3 \mathrm{~km}$ depth, and possibly continue at this dip to depths of $6 \mathrm{~km}$. This result has important implications for determining the state of stress required to activate the faults and is being followed up by seismological observations using a system of permanent and temporary seismological stations (Karlsson et al., 2010).

Published by Copernicus Publications on behalf of the European Geosciences Union. 


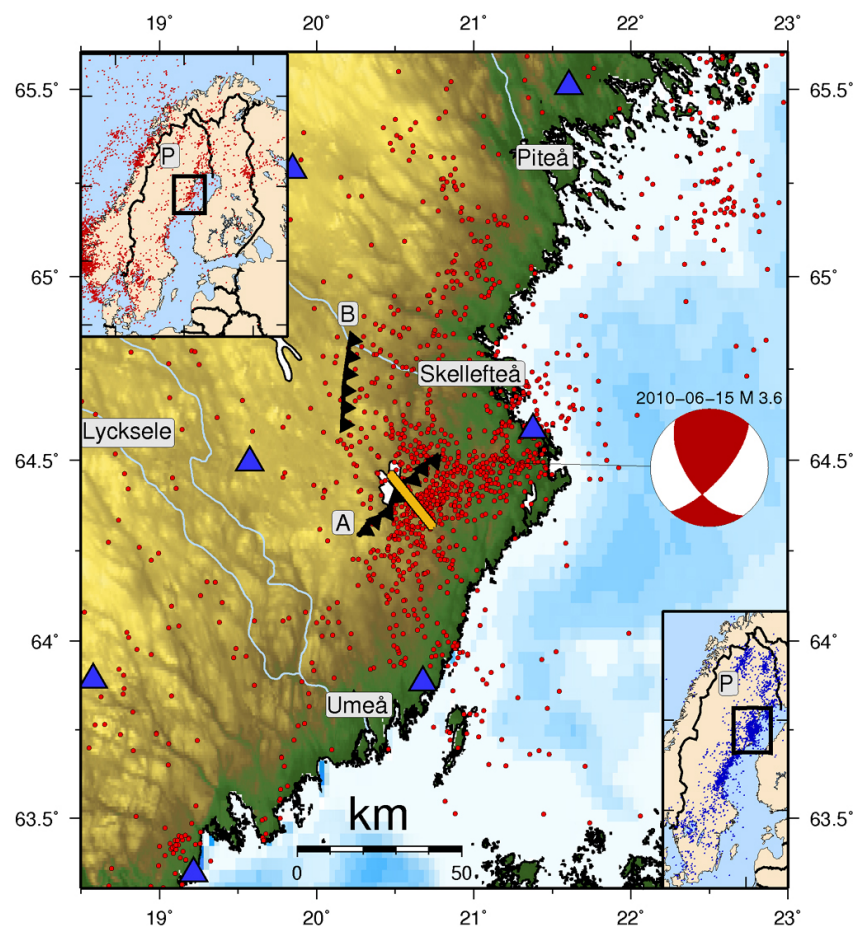

Fig. 1. Seismicity and postglacial faults in the Skellefteå area. Fault A is the Burträsk fault and fault B the Röjnoret fault. The P in the insets shows the location of the southwestern end of the Pärvie fault. Red dots are earthquakes located by the Swedish National Seismic Network (SNSN) since 2000, blue triangles show SNSN stations and the yellow line is the reflection profile. Focal mechanisms of the 15 June 2010, M3.6 earthquake. The upper left inset shows the seismicity of Fennnoscandia between 1960 and 2001 from the University of Helsinki FENCAT catalogue. The lower right inset shows the seismicity of Sweden recorded by the SNSN between 2000 and June 2010.

In addition, there is now an international initiative underway to drill into some of the end-glacial faults in the Nordic countries (Kukkonen et al., 2010) in a systematic manner.

In this paper we report on results from the next stage of our studies, that is a reflection seismic survey over the Burträsk fault, near the city of Skellefteå in northern Sweden. This fault was chosen for the survey since the Skelleftea area is one of the most seismically active areas in all of Sweden (Fig. 1). Data were recorded along a ca. $22 \mathrm{~km}$ long profile in the summer of 2008. First we show the main results from the seismic data and how they relate to the Burträsk end-glacial fault. We then discuss the possible origin of some of the other zones of reflectivity observed in the profile and speculate on how the seismic data may be relevant for mineral prospecting in the area. Finally, we draw some conclusions on the seismological implications of the reflection seismic survey results.

\section{Geological setting}

The surface trace of the Burträsk end-glacial fault cuts mainly across high-grade meta-greywackes and metaargillites of the Robertsfors Group (Nisca, 1995; Rutland et al., 2001). These rocks are on the order of $1.96-1.88 \mathrm{Ga}$ (Kathol and Weihed, 2005), although there is some debate about their age (e.g., Weihed, 2003; Skiöld and Rutland, 2009; Högdahl and Lundqvist, 2009), as well as the tectonic evolution of the area (see Lahtinen et al., 2009). Further to the northwest, acidic intrusives are common (Fig. 2). These intrusives, along with some volcanic rocks and the meta-sedimentary rocks mentioned above form a wider dextral strike-slip shear zone referred to as the Burträsk Shear Zone (BSZ in Fig. 2) by Romer and Nisca (1996). Rutland et al. (2001) subdivided the Burträsk Shear Zone into the Bursiljum sub-zone and the discrete Bygdeträsk Shear Zone. The latter of these correlates with the occurrence of some larger nickel deposits northeast of the seismic profile (Fig. 2). For this paper we retain the simpler definition by Romer and Nisca (1996) of the east-northeast striking Burträsk Shear Zone (BSZ) that roughly separates rocks that are dominated by acidic intrusives to the north of it from mainly metasedimentary rocks to the south of it.

The surface trace of the Burträsk fault itself has been mapped using air photos and has been interpreted as a reverse fault that dips to the southeast The scarp height varies between 5 to $10 \mathrm{~m}$ and locally reaches $15 \mathrm{~m}$ (Lagerbäck and Sundh, 2008). The fault appears to cut across the magnetic anomaly pattern southwest of the seismic profile, but becomes parallel to the geological structure and magnetic anomaly pattern northeast of the profile. Close to where the mapped fault crosses the profile the surface trace of the fault turns sharply and has an orientation that is close to parallel to the profile for a distance of about $2 \mathrm{~km}$.

Based on liquefaction structures south of the Burträsk fault, Mörner (2005) interpreted two paleoseismic events at the end of the last glaciation. These are separated by 135 years and dated at varves 9428 and 9293 BP. Based on these events and other data, Mörner (2005) suggested a magnitude 7 earthquake caused the surface rupture of the Burträsk fault.

\section{Current seismicity}

From the instrumental record we know that the Skelleftea area and the Lake Vänern area are Sweden's two most earthquake prone areas (upper left inset in Fig. 1). The first historical record of an earthquake in the Skellefteå area dates back to 1706 (Kjellén, 1910). In the 1960's, an average of 1 to 2 events per year were recorded in the Skellefteå area, as defined by Fig. 1. However, as detection capabilities increased the rate of recorded events increased to approximately 5 events per year during the 1990's. With the upgrade and expansion of the Swedish National Seismic Network (SNSN) 

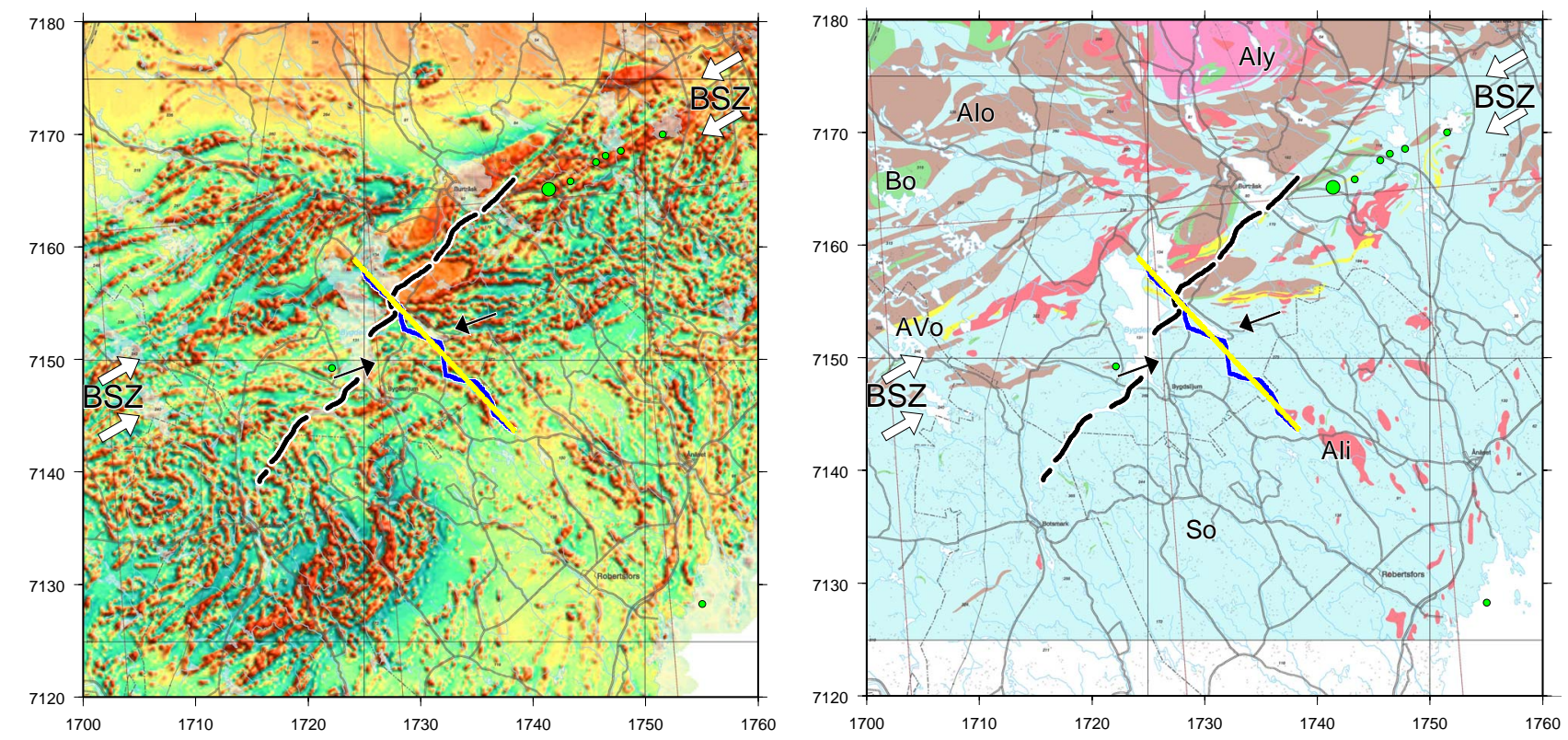

Fig. 2. Seismic profile (blue line) plotted on the residual magnetic field anomaly map (left) and the overview geological map (right). Yellow line is the CDP processing line. Black curve shows the surface trace of the Burträsk fault. Magnetic and geological maps are courtesy of the Geological Survey of Sweden (SGU). Large green circle shows the Lappvattnet nickel mine (now closed) and the smaller green circles are mineral deposits of nickel based on data from Kathol and Weihed (2005). White arrows show the approximate location of the Burträsk Shear Zone (BSZ). Black arrows indicate a topographic low. AIy - Acidic intrusive rocks (1.87-1.66 Ga), AIi - Acidic intrusive rocks (1.87-1.75 Ga), Bo - Basic intrusive and volcanic rocks (1.96-1.86 Ga), AIo - Acidic intrusive rocks (1.96-1.86 Ga), AVo - Acidic volcanic rocks $(1.96-1.86 \mathrm{Ga})$, So - Sedimentary rocks $(1.96-1.86 \mathrm{Ga})$.

during 1998-2008 (Bödvarsson and Lund, 2003), the number of detected and located earthquakes in Sweden has increased by orders of magnitude (lower right inset in Fig. 1, note that the SNSN has had stations in SW Sweden only since 2007). Since 2002, when the north coast section of the SNSN was constructed, the seismicity rate in the Skelleftea area has been approximately 140 events per year. SNSN earthquake locations for the area are shown in Fig. 1. The seismicity in the central region is strongly correlated with the mapped surface expression of the Burträsk fault and most of the events are located southeast of the fault, in general agreement with a southeast dipping thrust fault. The single-event depth determinations are not accurate enough to allow an interpretation in terms of one or more faults planes, but the majority of earthquakes occur from shallow depths down to approximately $30 \mathrm{~km}$. Ongoing work with double-difference relocation may improve these hypocentral locations significantly. East of the northeastern end of the mapped fault the band of seismicity continues to the northeast and as it approaches the coast it seems to split into two segments, a northerly and a southerly. At the southwestern end of the fault there seems to be migration of the seismicity southward. Interestingly, there is much less seismicity associated with the north-south striking Röjnoret fault (Fig. 1), which is also of end-glacial origin (Lagerbäck and Sundh, 2008).
Since the installation of Sweden's first seismograph in Uppsala in 1904, 39 earthquakes with magnitude M 3 or above have been reported for the Skellefteå area. There are historical inferences of M 4 events, the latest occurring in 1909 (Renqvist, 1930), but with significant uncertainty. Since 2002 there have been three $M_{\mathrm{L}}>3$ earthquakes in the area, the largest of which occurred on 15 June 2010, and had $M_{\mathrm{L}} 3.6$ (Fig. 1). The June 2010 event was located approximately $25 \mathrm{~km}$ east of the northeastern end of the surface trace of the Burträsk fault. It was followed by 11 aftershocks large enough to be recorded on three or more stations, with magnitudes ranging from 1 to -0.3 . Additionally, tens of smaller aftershocks are present in the continuous waveform data from the closest station. The focal mechanism of the main event, see Fig. 1, shows a dominating strike-slip motion and has one nodal plane with strike $42^{\circ}$ and dip $70^{\circ}$, the strike in general agreement with the strike of the Burträsk fault. Focal mechanism determinations for the larger events along the fault show a similar pattern with one nodal plane in approximate agreement with the strike of the Burträsk fault and general strike-slip motion. If the NE-SW striking plane is considered the fault plane, the motion is right-lateral. There are a small number of reverse faulting events, but although the main end-glacial earthquake was a thrust event, current deformation is predominantly strike-slip. 
Table 1. Acquisition parameters for the reflection seismic experiment.

\begin{tabular}{ll}
\hline Spread type & Asymmetric split \\
\hline Number of channels & $280(60-220)$ \\
Near offset & $0 \mathrm{~m}$ \\
Geophone spacing & $20 \mathrm{~m}$ \\
Geophone type & $28 \mathrm{~Hz}$ single \\
Source spacing & $20 \mathrm{~m}$ \\
Source type & VIBSIST \\
Hit interval between hammer blows & $100-200 \mathrm{~ms}$ \\
Sweeps per source point & $3-4$ \\
Nominal fold & 140 \\
Recording instrument & SERCEL 408UL \\
Sample rate & $1 \mathrm{~ms}$ \\
Field low cut & Out \\
Field high cut & $400 \mathrm{~Hz}$ \\
Record length & $23 \mathrm{~s}$ \\
Profile length & $22 \mathrm{~km}$ \\
Source points & 799 \\
Dates acquired & $5 / 8-16 / 8,2008$ \\
\hline
\end{tabular}

We are currently working on improving the earthquake analysis, both in the Skellefteå and Pärvie areas, in order to obtain better constraints on the location, depth and focal mechanisms of the events to thoroughly investigate their association with the end-glacial faults.

\section{Data acquisition}

Similar acquisition parameters and source were used as for the Pärvie fault system profile (Juhlin et al., 2010) with the goal of imaging the uppermost $5 \mathrm{~km}$ of crust. Again, an hydraulic hammer, VIBSIST (Cosma and Enescu, 2001), was used to generate the seismic signal along a ca. $22 \mathrm{~km}$ long profile (Fig. 2). The vehicle mounted hammer hit the ground repeatedly at an increasing rate for a predetermined time span. The recorded signals were then processed using a shift and stack method (e.g., Park et al., 1996) to generate seismograms for further processing. Geophones with a natural frequency of $28 \mathrm{~Hz}$ were used, with a station spacing of $20 \mathrm{~m}$. In total, about 800 shot points were activated along the profile with nominally $3-4$ sweeps per source point and a nominal source spacing of $20 \mathrm{~m}$. Other details on the acquisition are given in Table 1. Sources could not be activated in areas within $50 \mathrm{~m}$ of residential housing. This led to uneven coverage along some parts of the profile, particularly in the northwestern part. Analysis of raw shot gathers indicates that the data quality is generally good, with clear reflections visible after limited processing (Fig. 3).
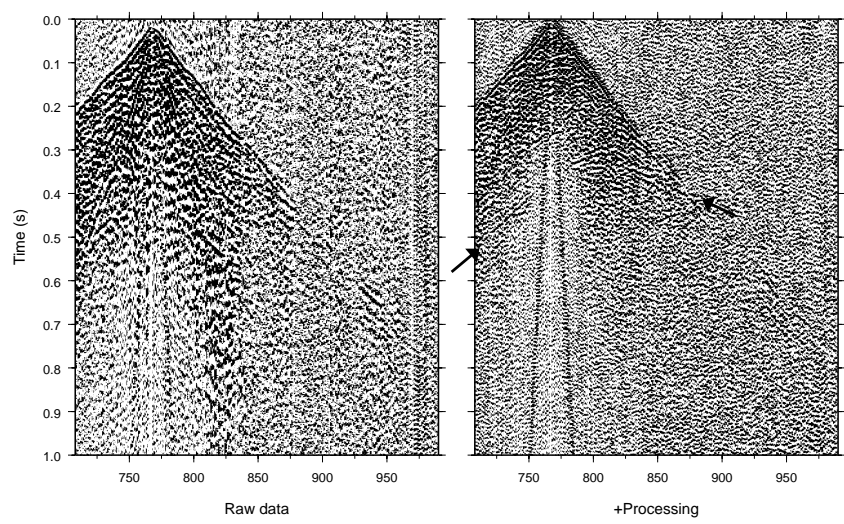

Fig. 3. Example of a shot gather without (left) and with (right) refraction statics and temporal filtering. Arrows mark a steeply dipping reflection that intersects the surface close to station 900 . Horizontal axis is receiver station.

\section{Data processing}

After decoding of the VIBSIST source records using the shift-and-stack method (Park et al., 1996), the geometry of the sources and receivers was added to the source gathers and the data were binned along a straight stacking line into $10 \mathrm{~m}$ wide Common Data Point (CDP) bins. As in most hard rock areas, refraction statics was an important processing step (e.g. Wu and Mereu, 1992; Juhlin, 1995). For refraction statics, first breaks were picked automatically on all source gathers in the offset interval $0-4000 \mathrm{~m}$ and then manually edited. A starting model consisting of a $10 \mathrm{~m}$ thick overburden with the velocity set to $1000 \mathrm{~m} \mathrm{~s}^{-1}$ and bedrock with the velocity set to $5500 \mathrm{~m} \mathrm{~s}^{-1}$ produced the model with the least residual (about $5 \mathrm{~ms}$ ) for those starting models tested. In contrast to the Pärvie profile, application of Dip MoveOut (DMO) improved the image, allowing both more subhorizontal and steeply dipping reflections to be imaged simultaneously (Fig. 4). The DMO processed stack was then migrated using a finite-difference migration routine and then depth converted (Fig. 5). If the reflections are from withinthe-plane of the profile the migration process should locate them at their correct spatial position and the corresponding dips on the migrated section should be close to true dips. More steeply dipping reflections are more likely to be closer to within-the-plane of the profile than sub-horizontal ones. A complete list of the processing steps is given in Table 2 .

\section{Discussion}

\subsection{The Burträsk fault}

The surface trace of the Burträsk fault intersects the CDP stacking line at about CDP 1700 and the receiver line at about station 900 (Fig. 6). On the stacked seismic section 


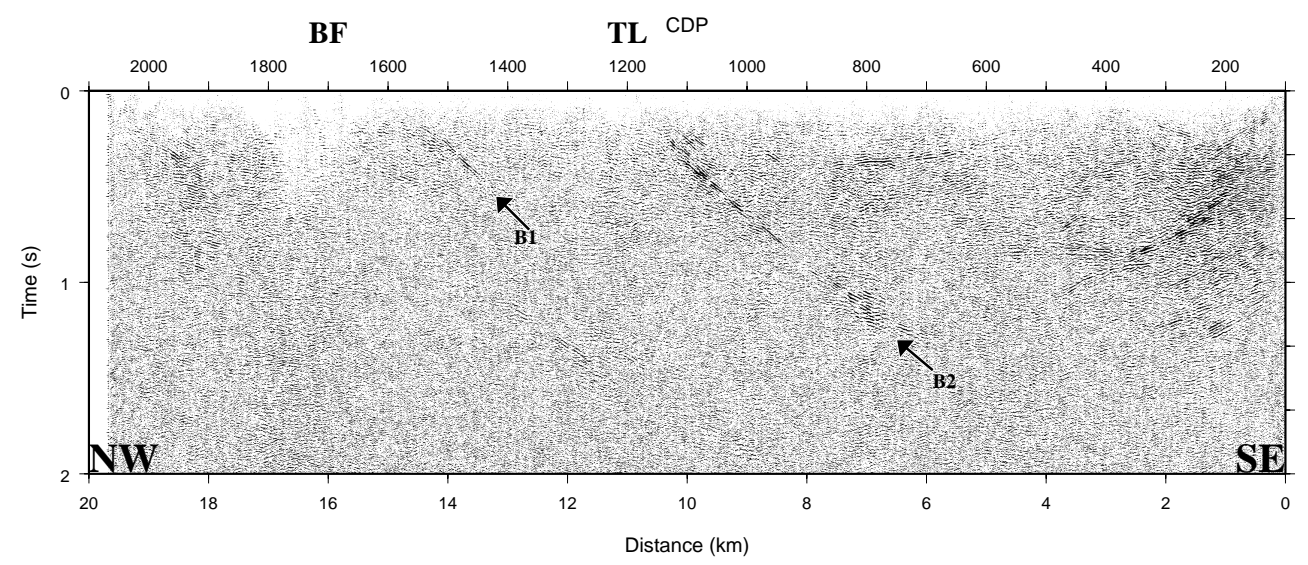

Fig. 4. Stacked section along the Buträsk profile. Surface location of where the profile crosses the Burträsk fault (BF) and a topographic low (TL) are shown. Reflections B1 and B2 are discussed in the text.

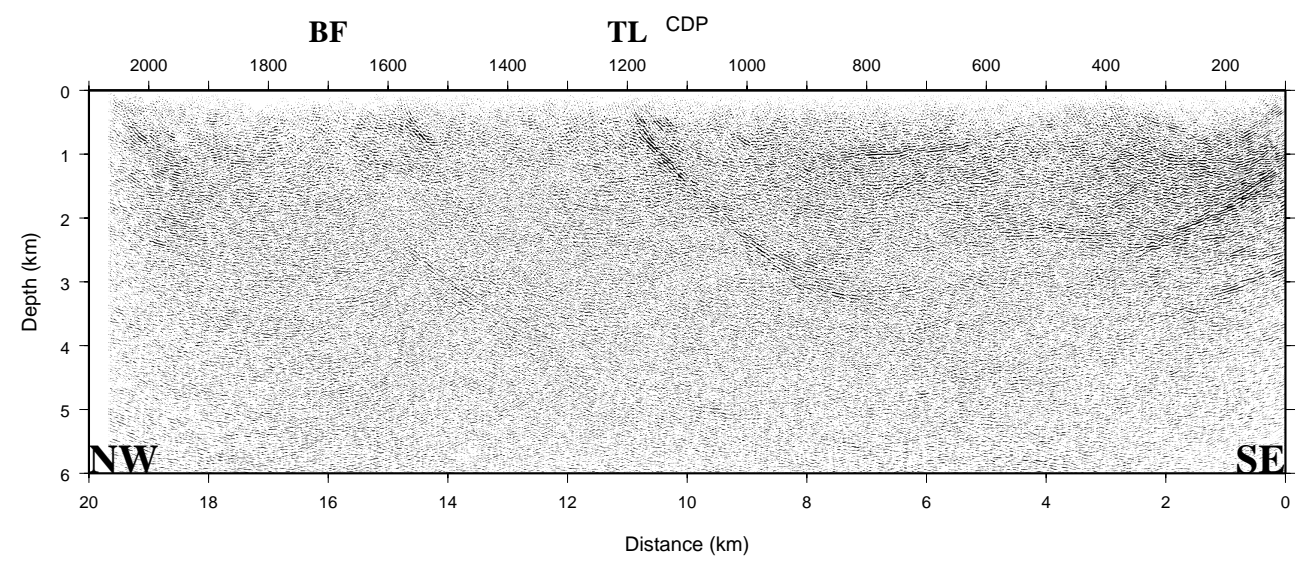

Fig. 5. Depth converted migrated section along the Buträsk profile. Surface location of where the profile crosses the Burträsk fault (BF) and a topographic low (TL) are shown.

(Fig. 4) there is a clear dipping reflection (B1) that projects to the surface at CDP 1600 , about $1 \mathrm{~km}$ to the southeast of the Burträsk fault. However, the Burträsk fault scarp jumps to the northwest by about $1 \mathrm{~km}$ as the seismic profile is approached from the southwest. We interpret the B1 reflection to be from that portion of the Burträsk fault that projects into the CDP line at CDP 1600. This is reasonable since the actual acquisition profile (Fig. 6) lies to the southeast of this section of the fault, not the more northeasterly section that intersects the CDP line at CDP 1700. The choice of acquisition line was not optimal for imaging the fault, however, given the paucity of roads crossing the fault there was little choice. Note that we do see reflections from the fault where the seismic profile crosses it. The steeply dipping reflection seen in the shot gather in Fig. $3 \mathrm{~b}$ intersects the surface close to where the fault is mapped. The relatively poor image of the fault in the stacked section is attributed to the crookedness of the profile in the area of the fault and the fault geometry itself. Processing the crooked line data as 3-D data may al- low a better image to be obtained. Such a strategy has been successful at other locations (e.g. Malehmir et al., 2009). Modeling of reflection traveltimes as done on the Pärvie profile (Juhlin et al., 2010) shows that structures striking N35E and dipping $55^{\circ}$ are consistent with the seismic data. This dip is similar to that of the main fault of the Pärvie system (Juhlin et al., 2010). Given that the Burträsk fault shows a top-to-the-northwest sense of motion (Lagerbäck and Sundh, 2008), then the fault geometry as determined from the reflection seismic data implies that it is a reverse fault.

\subsection{Other zones of reflectivity}

Aside from the reflections associated with the Burträsk fault, there are a number of other zones of reflectivity on the seismic section (Fig. 4). The most spectacular is, perhaps, the steeply dipping B2 reflection zone. This reflection zone projects to the surface near CDP 1200 , in the middle of a topographic low (Fig. 6), suggesting that it originates from a fault zone. Assuming that it is a fault zone associated with 
Table 2. Processing steps for the reflection seismic experiment.

\begin{tabular}{|c|c|}
\hline Step & Parameters \\
\hline 1 & Read decoded VIBSIST data \\
\hline 2 & Bulk static shift to zero time \\
\hline 3 & Apply geometry \\
\hline 4 & Pick first breaks \\
\hline 5 & Resample: $2 \mathrm{~ms}, 1501$ samples \\
\hline 6 & Trace editing \\
\hline 7 & Trace balance: $0-3000 \mathrm{~ms}$ \\
\hline 8 & Spectral equalization: $25-40-120-150 \mathrm{~Hz}$ \\
\hline \multirow[t]{5}{*}{9} & Time variant bandpass filter: \\
\hline & 0-200 ms: $35-70-200-300 \mathrm{~Hz}$ \\
\hline & 250-500 ms: $30-60-180-270 \mathrm{~Hz}$ \\
\hline & $600-900 \mathrm{~ms}: 22-45-135-200 \mathrm{~Hz}$ \\
\hline & $1100-3000 \mathrm{~ms}: 20-40-120-180 \mathrm{~Hz}$ \\
\hline 10 & $\begin{array}{l}\text { Refraction statics: datum } 200 \mathrm{~m} \text {, } \\
\text { replacement velocity } 5500 \mathrm{~m} \mathrm{~s}^{-1} \text {, } \\
\text { overburden velocity } 1600 \mathrm{~m} \mathrm{~s}^{-1}\end{array}$ \\
\hline 11 & Residual statics \\
\hline 12 & AGC: $100 \mathrm{~ms}$ window \\
\hline 13 & $\begin{array}{l}\text { Median filter: } 11 \text { traces, } 3 \text { samples, } \\
5300 \mathrm{~m} \mathrm{~s}^{-1} \text {, subtract }\end{array}$ \\
\hline 14 & Butterworth filter: 20-40-200-300 \\
\hline 15 & Residual statics \\
\hline 16 & Velocity analysis \\
\hline 17 & NMO correction: $40 \%$ stretch mute \\
\hline 18 & DMO \\
\hline 19 & Stack \\
\hline 20 & Trace balance \\
\hline 21 & FX Decon: 19 trace window \\
\hline 22 & Finite difference migration: $0-5400 \mathrm{~ms}^{-} \mathrm{m} \mathrm{s}^{-1}$ \\
\hline 23 & Depth conversion: $0-5400 \mathrm{~ms}^{-\mathrm{m} \mathrm{s}^{-1}}$ \\
\hline
\end{tabular}

the topographic low, then a structure striking N70E and dipping at $75^{\circ}$ to the southeast would generate reflections that match those seen in the stacked section. This structure extends to at least a depth of $3 \mathrm{~km}$ (Fig. 5) where it appears to become more listric. However, it may extend to greater depths at this orientation, but the impedance contrast may be less. Alternatively, the source strength may not have been sufficient to image it deeper. There are no indications that this fault, if it is one, was active during the last deglaciation (R. Lagebäck, personal communication, 2010). The implications of this reflection zone concerning present-day earthquake activity and its relevance for mineral prospecting are discussed in the next sections. It is also interesting to note that reflections were observed east of the Pärvie fault system that likely originate from fault zones that did not have large displacements occurring along them at the end of the last glaciation (Juhlin et al., 2010).

Three other zones of increased reflectivity are observed along the profile; (i) a southeast dipping zone at the northwestern end of the profile, (ii) a sub-horizontal zone at about

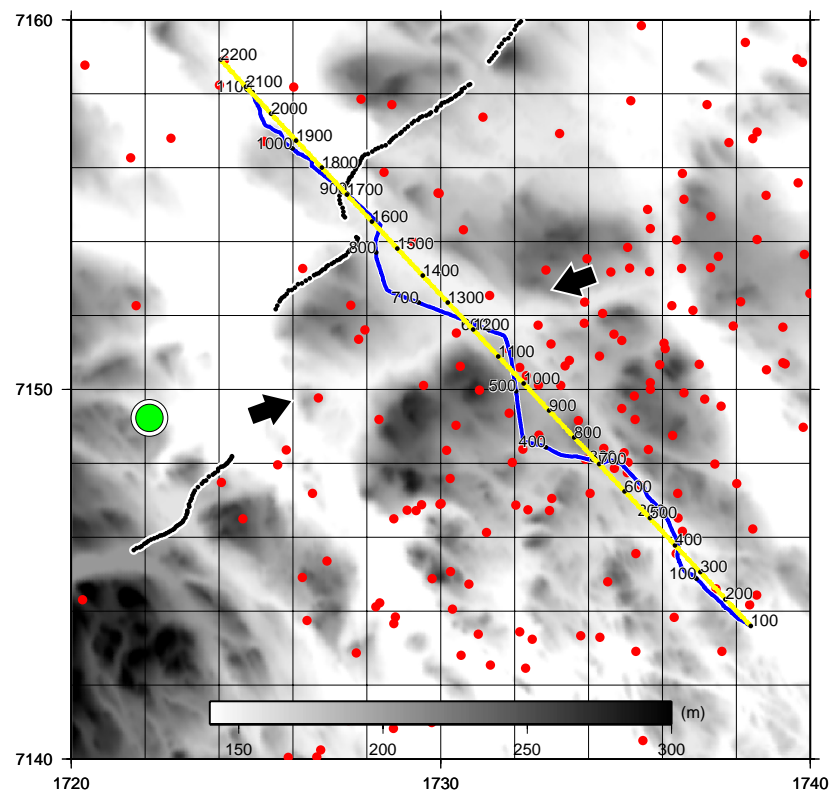

Fig. 6. CDP stacking line (yellow) and receiver line (blue) plotted on the topographic map. CDP and station numbers are shown in black. Black curve marks the mapped Burträsk end-glacial fault. Arrows indicate a substantial topographic low that crosses the CDP stacking line at about CDP 1200 . Green circle represents a nickel deposit. Red dots show locations of earthquake epicenters from single event determinations.

$1 \mathrm{~km}$ depth between CDP 600 and 900, and (iii) a northwest dipping zone at the southeastern end of the profile. These zones may indicate changes in lithology at depth, rather than being related to fault zones. Variations of lithology within the supracrustal sequences or more mafic rocks may explain the increased reflectivity.

\subsection{Relationship to the "Nickel Zone"}

Both the Burträsk fault and the nickel deposits in the area, the "Nickel Zone", lie within the Burträsk Shear Zone (Fig. 2). The nickel deposits in the area are magmatic in origin and related to mafic and ultramafic intrusions (Kathol and Weihed, 2005). Most of the deposits are non-economic, but the Lappvattnet deposit (Fig. 2) was mined (Kathol and Weihed, 2005) and the area has been given renewed interest by mining companies in recent years. Given that the nickel mineralizations are associated with more mafic rocks implies that seismic methods may be suitable for identifying mafic targets at depth and dipping shear zones that may have facilitated the intrusion of mafic and ultramafic magmas. The topographic low corresponding to the pronounced steeply dipping reflection (B2 in Fig. 4) projects into a known occurrence of nickel mineralization to the west. Furthermore, some of the shorter high amplitude reflections seen on the seismic section, for example the dipping reflection at $1 \mathrm{~km}$ depth at CDP 1000 and 
the sub-horizontal reflection at the same depth below CDPs 800-900 in Fig. 5, may represent mafic or ultramafic bodies. Possible deep drilling in the area (Kukkonen et al., 2010) would further investigate these possibilities.

\subsection{Seismicity and the Burträsk fault}

The seismicity in the vicinity of the Burträsk fault seems to be associated with the fault, both because it follows a similar strike direction and because it is mostly located southeast of the fault, as expected for a southeastward dipping fault. The eastward continuation of the seismicity where no fault has been mapped may indicate a continuation of a weak zone to the east. There is, however, also a north-south trend in the seismicity which is not explained by the mapped fault or the imaged fault zones. Higher accuracy, multi-event relocation is necessary to better constrain the location of the events.

The depth control on the routine, single-event earthquake locations is not accurate enough to allow the events to be associated with any particular fault, or to allow the determination of a common fault plane. Multi-event analysis is currently being investigated in order to more precisely determine the depths and relative event relocation will be attempted. The routine depth estimates indicate that we have earthquakes southeast of the Burträsk fault distributed from near the surface to approximately $30 \mathrm{~km}$ depth. The shallow events offer a possibility to link the reflection seismic results presented here to deeper structures mapped by the earthquakes. The reflectors B1 and B2 found here are only $4 \mathrm{~km}$ apart at the surface so it may be difficult to discriminate between them using the earthquakes. If the earthquakes are indeed associated with the end-glacial fault, then the deep earthquakes indicate that the fault does not become listric. The possible listric shape of the $\mathrm{B} 2$ reflection may be a relic due to the hotter environment that the fault zone first formed in, it is not due to the brittle-ductile transition in the presentday crust.

The relative absence of seismicity on the north-south striking Röjnoret fault (Fig. 1) is interesting in comparison to the abundance near the Burträsk fault. The longstanding debate on whether the east coast earthquakes of northern Sweden are caused by tectonic or deglaciation stresses (Bungum et al., 2005) is important in this respect as the Skelleftea area has the highest uplift rates in Fennoscandia (Lidberg et al., 2010). We note, however, that preliminary focal mechanisms determinations point to a dominating strike-slip regime. Careful analysis of the focal mechanisms and the prevailing stress field, including estimates of remaining glacial stresses (e.g. Lund et al., 2009), may shed further light on the matter.

\section{Conclusions}

High resolution reflection seismic profiling over the endglacial Burträsk fault shows that the fault zone dips at about $55^{\circ}$ to the southeast. It can be traced down to a depth of about $1 \mathrm{~km}$, after which the image becomes unclear. The geometry of the fault zone itself and the crookedness of the seismic profile in the vicinity of the fault may contribute to the lack of clarity in the image. The dip of the fault is consistent with it being a reverse fault with a top to the northwest sense of motion, as interpreted from surface geological observations. Further to the southeast, a much more pronounced reflection is observed that intersects the surface at a marked topographic low and extends to at least $3 \mathrm{~km}$ depth. This reflection is interpreted to originate from a steeply dipping fault or fracture zone that did not experience significant displacement as the last glacial ice receded. Other reflections along the profile are interpreted as originating from lithological contrasts in the supra-crustal rocks or from more mafic intrusions, the latter of which may be related to mineral deposits in the area. At present it is not possible to directly couple neither the Burträsk fault, nor the fault zone associated with the pronounced reflection, to the earthquake activity in the area. However, more precise locating of the hypocenters in the future may allow the fault geometries observed in the upper few $\mathrm{km}$ to be extended to the deeper parts of the crust.

Acknowledgements. The Swedish Research Council (VR) funded the reflection seismic data acquisition and are gratefully acknowledged. GLOBE ClaritasTM under license from the Institute of Geological and Nuclear Sciences Limited, Lower Hutt, New Zealand was used to process the seismic data.

Edited by: T. Iwasaki

\section{References}

Arvidsson, R.: Whole crustal rupturing related to postglacial rebound, Science, 274, 744-746, 1996.

Bödvarsson, R. and Lund, B.: The SIL seismological data acquisition system - as operated in Iceland and in Sweden, in: Methods and Applications of Signal Processing in Seismic Network Operations, edited by: Takanami, T. and Kitagawa, G., Lecture Notes in Earth Sciences, Springer, Berlin, 98, 131-148, 2003.

Bungum, H., Lindholm, C. and Faleide, J. I.: Postglacial seismicity offshore mid-Norway with emphasis on spatio-temporalmagnitudal variations, Marine Petroleum Geol., 22, 137-148, doi:10.1016/j.marpetgeo.2004.10.007, 2005.

Cosma, C. and Enescu, N.: Characterization of fractured rock in the vicinity of tunnels by the swept impact seismic technique, Int. J. Rock Mech. Min., 38, 815-821, 2001.

Henkel, H.: Tectonic studies in the Länsjärv area, SKB (Swedish Nuclear Fuel and Waste Management Co.) Report no. TR-88-07, 1988 . 
Högdahl, K. and Lundqvist, Th.: Discussion on "Succesive $\sim 1.94 \mathrm{Ga}$ plutonism and $\sim 1.92 \mathrm{Ga}$ deformation and metamorphism south of the Skellefte district, northern Sweden: substantiation of the marginal basin accretion hypothesis of Svecofennian evolution" by T. Skiöld and R. W. R. Rutland (Precambrian Res., 148, 181-204, 2006), Precambrian Res., 168, 330-334, 2009.

Juhlin, C.: Imaging of fracture zones in the Finnsjön area, central Sweden, using the seismic reflection method, Geophysics, 60, 66-75, 1995.

Juhlin, C., Dehghannejad, M., Lund, B., Malehmir, A., and Pratt, G.: Reflection seismic imaging of the end-glacial Pärvie Fault system, northern Sweden, J. Appl. Geophys., 70, 307-316, doi:10.1016/j.jappgeo.2009.06.004, 2010.

Kathol, B. and Weihed, P.: Description of regional geological and geophysical maps of the Skellefte District and surrounding areas, SGU Ba57, ISBN: 91-7158-678-4, 197 pp., 2005.

Kjellén, R.: Sveriges jordskalf: försök till en seismisk landsgeografi, Göteborg s.n., 211 pp., 1910 (in Swedish).

Kukkonen, I. T., Olesen, O., Ask, M. V. S., and the PFDP Working Group: Postglacial Faults in Fennoscandia: Targets for scientific drilling, GFF, 132, 71-81, 2010.

Lagerbäck, R.: Late Quarternary faulting and paleoseismicity in northern Fennoscandia, with particular reference to the Länsjärv area, northern Sweden, Geol. Foren. Stock. For., 112, 333-354, 1990.

Lagerbäck, R. and Sundh, M.: Early Holocene faulting and paleoseismicity in northen Sweden, Swedish Geological Survey, Research Paper C 836, 80 pp., 2008.

Lahtinen, R., Huhma, H., Kahkonen, Y., and Manttari, I.: Paleoproterozoic sediment recycling during multiphase orogenic evolution in Fennoscandia, the Tampere and Pirkanmaa belts, Finland, Precambrian Res., 174, 310-336, doi:10.1016/j.precamres.2009.08.008, 2009.

Lidberg, M., Johansson, J. M., Scherneck, H.-G., and Milne, G. A.: Recent results based on continuous GPS observations of the GIA process in Fennoscandia from BIFROST, J. Geodyn, 50, 8-18, doi:10.1016/j.jog.2009.11.010, 2010.

Lund, B. and Näslund, J.-O.: Glacial isostatic adjustment: Implications for glacially induced faulting and nuclear waste repositories, in: Volcanic and Tectonic Hazard Assessment for Nuclear Facilities, edited by: Connor, C. B., Chapman, N. A., and Connor, L. J., Cambridge University Press, Cambridge, UK, 640 pp., 2009.

Lund, B., Schmidt, P., and Hieronymus, C.: Stress evolution and fault stability during the Weichselian glacial cycle, TR-0915, Swedish Nuclear Fuel and Waste Management Co. (SKB), Stockholm, Sweden, 106 pp., 2009.
Malehmir, A., Schmelzbach, C., Bongajum, E., Bellefleur, G., Juhlin, C., and Tryggvason, A.: 3D constraints on a possible deep $>2.5 \mathrm{~km}$ massive sulphide mineralization from $2 \mathrm{D}$ crooked-line seismic reflection data in the Kristineberg mining area, northern Sweden, Tectonophysics, 479, 223-240, doi:10.1016/j.tecto.2009.08.013, 2009.

Mörner, N.-A.: An interpretation and catalogue of paleoseismicity in Sweden, Tectonophysics, 408, 265-307, doi:10.1016/j.tecto.2005.05.039, 2005.

Nisca, D. H.: Nya litologiska - tektoniska modeller för regionen Västerbotten - södra Norrbotten, Ph.D. thesis 95:182, Luleå University of Technology, 1995.

Park, C. B., Miller, R. D., Steeples, D. W., and Black, R. A.: Swept impact seismic technique (SIST), Geophysics, 61, 1789-1803, 1996.

Renqvist, H.: Finlands jordskalv, Fennia, 54, 113 pp., 1930 (in Swedish).

Roberts, D., Olesen, O., and Karpuz, M. R.: Seismo- and neotectonics in Finnmark, Kola Peninsula and the southern Barents Sea. Part 1: Geological and neotectonic framework, Tectonophysics, 270, 1-13, 1997.

Romer, L. and Nisca, D. H.: Svecofennian crustal deformation of the Baltic Shield and U-Pb Age of Late-kinematic tonalite intrusions in the Burträsk Shear Zone, northern Sweden, Precambrian Res., 75, 17-29, 1995.

Rutland, R. W. R., Kero, L., Nilsson, G. and Stolen, L. K.: Nature of a major tectonic discontinuity in the Svecofennian province of northern Sweden, Precambrian Res., 112, 211-237, doi:10.1016/S0301-9268(01)00165-6, 2001.

Skiöld, T. and Rutland, R. W. R.: Succesive $\sim 1.94$ Ga plutonism and $\sim 1.92 \mathrm{Ga}$ deformation and metamorphism south of the Skellefte district: A reply to H\&L, Precambrian Res., 168, 335339, 2009.

Talbot, C.: A preliminary structural analysis of the pattern of postglacial faults in northern Sweden, SKB (Swedish Nuclear Fuel and Waste Management Co.) Report no. TR-86-20, 1986.

Weihed, P.: A discussion on papers "Nature of a major tectonic discontinuity in the Svecofennian province of northern Sweden" by Rutland et al. (Precambrian Res., 112, 211-237, 2001) and "Age of deformation episodes in the Palaeoproterozoic domain of northern Sweden, and evidence for a pre-1.91 Ga crustal layer" by Rutland et al. (Precambrian Res., 112, 239-259, 2001), Precambrian Res., 212, 141-147, 2003.

Wu, J. and Mereu, R. F.: Crustal structure of Kapuskasing uplift from LITHOPROBE near-vertical/wide-angle seismic reflection data, J. Geophys. Res., 97, 17441-17453, 1992. 